\title{
Comparison of the Skin Biophysical Parameters of Females Living in Beijing versus Kunming
}

Yifan He, Lizhi Yue, Yinmao Dong, Li Li, Hong Meng*

China Cosmetic Collaborative Innovation Center, Beijing Technology and Business University, Beijing, China

\author{
*Corresponding author: Hong Meng, \\ China Cosmetic Collaborative Innovation \\ Center, Beijing Technology and Business \\ University, No. 11/33, Fucheng Road, Haidian \\ District, Beijing, China \\ Tel.: +861068987110 \\ Email: menghong2000@163.com
}

Received December 20, 2017

Revised May 4, 2018

Accepted June 1, 2018

Published September 30, 2018

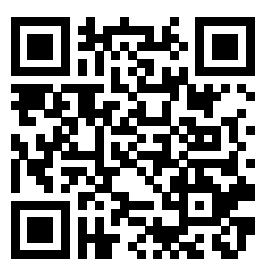

\begin{abstract}
Purpose: This study aimed to explore the differences of the biophysical parameters in the facial skin of Beijing and Kunming females so that it can provide practical application guidance for consumers in different regions. Also, this study would help the cosmetic enterprises devise cosmetics product more targeted according to particular features of various regions. Methods: 323 healthy women aged 21-69 years, according to the inclusive and exclusive criteria, from Beijing and Kunming enrolled in this study. We measured 6 biophysical characteristics including hydration, trans-epidermal water loss (TEWL), sebum content, $\mathrm{pH}$, melanin index (MI), erythema index (EI) by non-invasive method. Results: There were very significant regional differences of the skin biophysical parameters between Beijing and Kunming. In general, Kunming women showed lower sebum secretion and TEWL, higher hydration, $\mathrm{Ml}$ and El than Beijing women. Conclusion: Regions were an important factor which affected the skin physiological parameters. External circumstances and living habits differences were all considerations to evaluate skin condition. Research on skin biophysical parameters between different regions was essential to developing appropriate skincare strategies and devising cosmetics product more targeted.
\end{abstract}

Keywords: Skin biophysical parameters, Female, Beijing, Kunming, Trans-epidermal water loss

\section{Introduction}

As the largest and outermost human organ, skin is a protective barrier to exogenous substances and can be modulated by various internal and external factors, such as ethnic (Yamashita et al., 2012), age, gender (Firooz et al., 2012; Man et al., 2009), body site (Lee et al., 2013), seasonal variation, skin diseases (Darlenski et al., 2009) and etc. Also, region plays an important factor in determining the skin condition for the different of climate, UV radiation, temperature and humidity, daily activities and habits, etc.

After the reform and opening, China's cosmetics market is developing rapidly. China's huge population base brings the opportunity to the development of the cosmetics market. By the end of 2013, China's cosmetics market scale has reached $\$ 23.5$ billion, which accounted for ten percent of worldwide cosmetics consumer market, becoming the world's third largest market after the United States and Japan. What's more, by the end of 2015, retail figures released by the national bureau of statistics showed that the domestic cosmetics retail sales grew by 8.8\%, amounted to $\$ 31.5$ billion, even higher than GDP growth rate. China has become the world's second largest cosmetics market after the United States. As a result of the wide area and varied regional characteristics of China, it is necessary to investigate the alterations of skin biology in different regions for the design of cosmetic with regional characteristics,

To explore the differences between skin physiological 


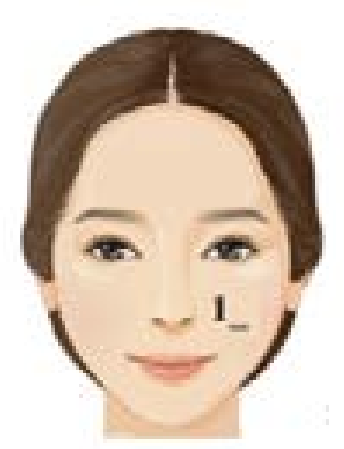

Figure 1. The biophysical parameters were measured on the left cheek (1).

The left cheek (1) region is around the junction of the vertical middle line of left eye and the tangent of nasal tip.

parameters of women at different age in different regions, we choose Beijing and Kunming as the comparison area. Beijing and Kunming respectively located in the northern and southern China, have two kinds of different climatic conditions (Table 1), living conditions, eating habits and etc.

Therefore, a specific study protocol was devised to collect comparable skin data in Beijing and Kunming women in order to determine and quantify the skin characteristics in each population. Six biophysical characteristics of normal skin (hydration, TEWL, sebum content, $\mathrm{pH}$, MI, EI) were measured in a normal population in different cities. It contributes to providing practical application guidance for skin care habits.

\section{Methods}

\section{Study design}

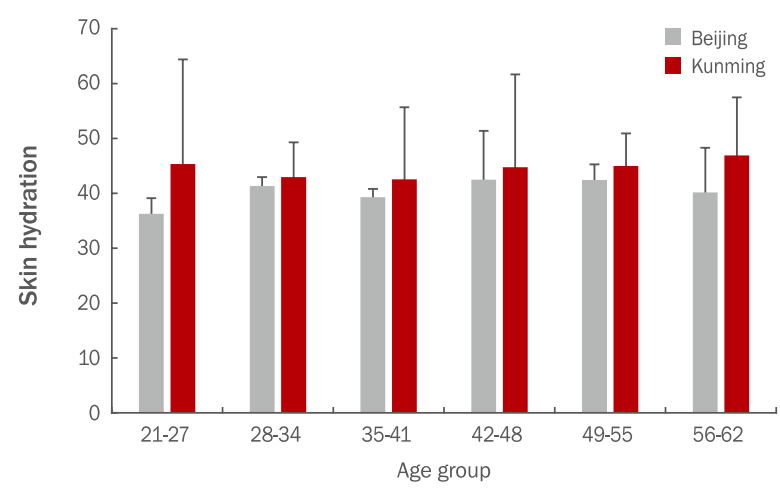

Figure 2. Mean values of skin hydration arranged by age group and cities.

150 women residing in Beijing and 173 women residing in Kunming were recruited and categorized as age 21-27, age 28-34, age 35-41, age 42-48, age 49-55, age 56-62. The Corneometer $\mathrm{CM}^{\circledR} 825$ was used to measure the skin hydration. There were no significant differences in the skin hydration between these two cities in all age groups. The data were expressed as $\mathrm{M} \pm \mathrm{SD}$ and the significant differences were analyzed by independent $t$ test method. $M \pm S D$, mean \pm standard deviation.

This study was cross-sectional study about female skin feature in Beijing city and Kunming city. The test was implemented in May 2010 and the data were obtained in a closed environment maintained at a mean standard deviation (SD) temperature of $22 \pm 2{ }^{\circ} \mathrm{C}$, relative humidity of $50 \% \pm 10 \%$. Prior to the taking of measurements, subjects were allowed to wash their facial with cleanser then have 20 min rest to equilibrate to the indoor conditions. Before the test, the volunteers were informed the test procedure, and signed the informed consent. Experiments conformed to the declaration of Helsinki. In this study, left cheek was deemed as target area for skin biophysical parameter testing place.

Table 1. Geographical information of Beijing and Kunming

\begin{tabular}{lcc}
\hline Characteristics & Beijing & Kunming \\
Climate & Temperate monsoon climate & Subtropical monsoon climate \\
Latitude & $39^{\circ} 54 "$ & $24^{\circ} 22^{\prime \prime}$ \\
Mean temperature $\left({ }^{\circ} \mathrm{C}\right)$ of spring & $1-12$ & $7-21$ \\
Altitude $(\mathrm{m})$ & 52 & 1930 \\
Spring average rainfall amount $(\mathrm{mm})$ & 12 & 18 \\
Light intensity $(\mathrm{klx})$ & $24-26$ & $>28$ \\
\hline
\end{tabular}

klx, kilolux. 


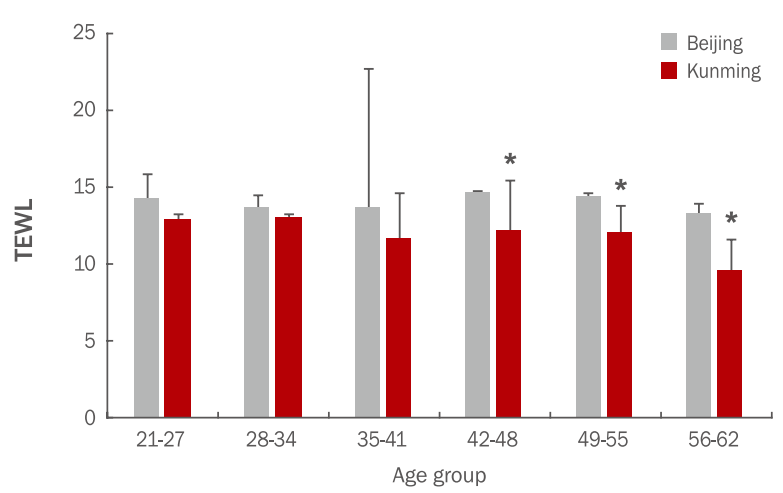

Figure 3. Mean values of TEWL arranged by age group and cities.

150 women residing in Beijing and 173 women residing in Kunming were recruited and categorized as age 21-27, age 28-34, age 35-41, age 42-48, age 49-55, age 56-62. TEWL was measured by using Tewameter ${ }^{\circledR}$ TM300. TEWL values in Kunming were general lower than in Beijing for each age groups and significantly decreases at age in the $42-48$ yearold age, 49-55 year-old age, and 56-62 year-old age group. The data were expressed as $\mathrm{M} \pm \mathrm{SD}$ and the significant differences were analyzed by independent $t$ test method. TEWL, trans-epidermal water loss; $\mathrm{M} \pm \mathrm{SD}$, mean \pm standard deviation; ${ }^{*} p<0.05$.

\section{Subjects}

This test was only for Han Chinese females and volunteers were recruited who had lived in Beijing and Kunming, respectively, for at least five years. 150 women residing in Beijing and 173 women residing in Kunming were enrolled this study. It is reported that woman body state will change with seven periods in the Chinese great medical ancient book Huangdi Neijing (Tian, 2005), so we divided respective population into six groups with seven years (group 1, 21-27 years; group 2, 28-34 years; group 3, 35-41 years; group 4, 42-48 years; group 5, 49-55; group 6, 56-62), which was different with the

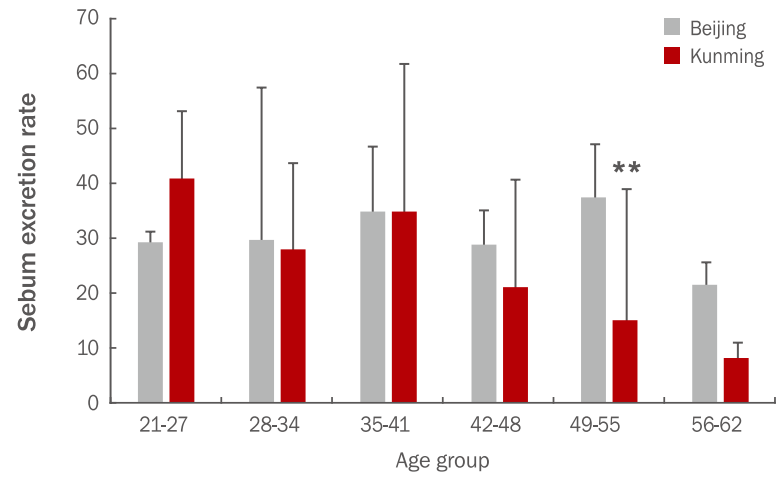

Figure 4. Mean values of sebum arranged by age group and cities.

150 women residing in Beijing and 173 women residing in Kunming were recruited and categorized as age 21-27, age 28-34, age 35-41, age 42-48, age 49-55, age 56-62. Skin sebum content was measured by using Sebumeter SM810. There was a significant lower of sebum secretion rate in Kunming women than that in Beijing in the 49-55 year-old age. The highest sebum was measured at 35-41 years-old in Beijing, whereas 56-62 years-old in Kunming showed the lowest mean sebum. The data were expressed as $\mathrm{M} \pm \mathrm{SD}$ and the significant differences were analyzed by independent $t$ test method. $\mathrm{M} \pm \mathrm{SD}$, mean \pm standard deviation; ${ }^{* *} p<0.01$.

existing population division.

Recruitment standards:

a) None of the subjects had significant skin disease such as psoriasis, eczema, etc., had taken any medications that could interfere with the study results, or had undergone any skin treatments (I.e. chemical peel, facial, microdermabrasion, collagen injection, retin-A or retinoid treatment, Botox therapy).

b) Women who were pregnant, lactating, or planning a pregnancy were excluded from entering the study.

The populations in 7-year age groups and their mean ages were shown in Table 2. They gave their written

Table 2. Distribution of subject populations in 7 years age gap

\begin{tabular}{|c|c|c|c|c|}
\hline \multirow{2}{*}{ Age group } & \multicolumn{2}{|c|}{ Beijing } & \multicolumn{2}{|c|}{ Kunming } \\
\hline & $\mathrm{N}$ & Age & $\mathrm{N}$ & Age \\
\hline $21-27$ & 29 & $26.6 \pm 4.2$ & 13 & $24.9 \pm 4.2$ \\
\hline $28-34$ & 39 & $31.2 \pm 4.2$ & 17 & $32.6 \pm 5.7$ \\
\hline $35-41$ & 14 & $38.3 \pm 4.2$ & 59 & $39.2 \pm 2.8$ \\
\hline $42-48$ & 23 & $45.2 \pm 4.2$ & 41 & $44.6 \pm 4.2$ \\
\hline 49-55 & 28 & $53.1 \pm 4.2$ & 31 & $52.2 \pm 4.2$ \\
\hline $56-62$ & 17 & $58.3 \pm 4.2$ & 12 & $57.9 \pm 2.8$ \\
\hline Total & 150 & & 173 & \\
\hline
\end{tabular}




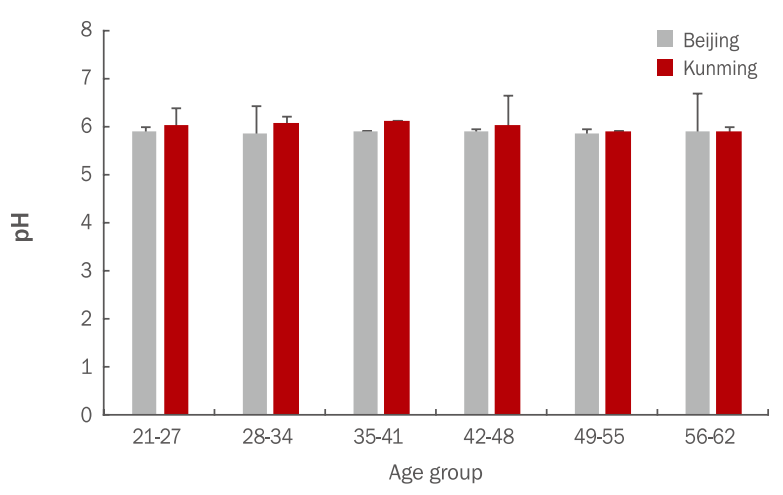

Figure 5. Mean values of $\mathrm{pH}$ arranged by age group and cities.

150 women residing in Beijing and 173 women residing in Kunming were recruited and categorized as age 2127 , age 28-34, age 35-41, age 42-48, age 49-55, age 56-62. Skin surface $\mathrm{pH}$ was measured with a flat glass electrode connected to a $\mathrm{pH}$ meter. There were no significant differences in the skin $\mathrm{pH}$ between these two cities in all groups. The data were expressed as $\mathrm{M} \pm \mathrm{SD}$ and the significant differences were analyzed by independent $t$ test method. $\mathrm{M} \pm \mathrm{SD}$, mean \pm standard deviation.

informed consent to participate in the study. The study protocol was approved by an internal review board.

\section{Biophysical measurement}

As showed in Figure 1, the biophysical parameters were measured on the left cheek (1) (Lee et al., 2013).

\section{1) Skin hydration}

The Corneometer ${ }^{\circledR}$ CM 825 (Courage+Khazaka electronic $\mathrm{GmbH}$, Germany) was used to measure the skin electrical capacitance, its principle was based on the fact that the dielectric constant of water is 81 and that of dry skin is below this. A normal value of stratum corneum hydration was accepted as higher than $40 \mathrm{u}$ (Lee et al., 2013).

\section{2) Skin transepidermal water loss}

Trans-epidermal water loss was measured by using Tewameter $^{\circledR}$ TM300 (Courage+Khazaka electronic GmbH). It reflects the degree of evaporation of water through the skin. Values were plotted and TEWL expressed as $\mathrm{g} / \mathrm{m}^{2} / \mathrm{h}$ (Hillebrand et al., 2001).

\section{3) Sebum excretion rate}

Skin sebum content was measured on the check by using Sebumeter SM810 (Courage+Khazaka electronic

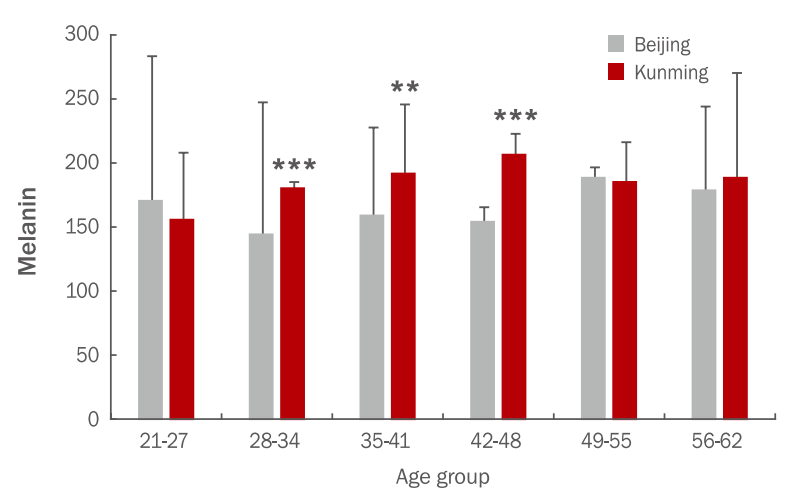

Figure 6. Mean values of melanin arranged by age group and cities.

150 women residing in Beijing and 173 women residing in Kunming were recruited and categorized as age 21-27, age 28-34, age 35-41, age 42-48, age 49-55, age 56-62. Skin melanin index were measured with Mexameter MX18. Skin melanin of Kunming was generally higher than Beijing. Specifically, the increase was very significant between the female subjects aged 28-34 year-old age and 42-48 year-old age. The data were expressed as $M \pm S D$ and the significant differences were analyzed by independent $t$ test method. $\mathrm{M} \pm \mathrm{SD}$, mean \pm standard deviation; ${ }^{* *} p<0.01 ;{ }^{* * *} p<0.001$.

$\mathrm{GmbH})$. The device measured variations in light intensity through a plastic strip. The values obtained were proportional to the quantity of sebum absorbed into the strip. The level of sebum was expressed as $\mu \mathrm{g} / \mathrm{cm}$ (Wan et al., 2015).

\section{4) Skin $\mathrm{pH}$}

Skin surface $\mathrm{pH}$ was measured with a flat glass electrode connected to a pH meter ( $\mathrm{pH}$ 900; Courage+Khazaka electronic $\mathrm{GmbH}$ ).

\section{5) Skin erythema and skin melanin}

Skin erythema and skin melanin index were measured with Mexameter MX18 (Courage+Khazaka electronic) (Lee et al., 2013). Similar to the Cutometer, the central portion of the probe of the Mexameter contains an elastic spring that ensures that constant pressure is applied to the skin. For each measurement the probe was held perpendicular to the skin and lightly touched to the skin surface, with no contact of the outer ring. This activated the light emitter resulting in an immediate display of the erythema and melanin index on the display console as arbitrary units (a.u.) such that the probe remained 


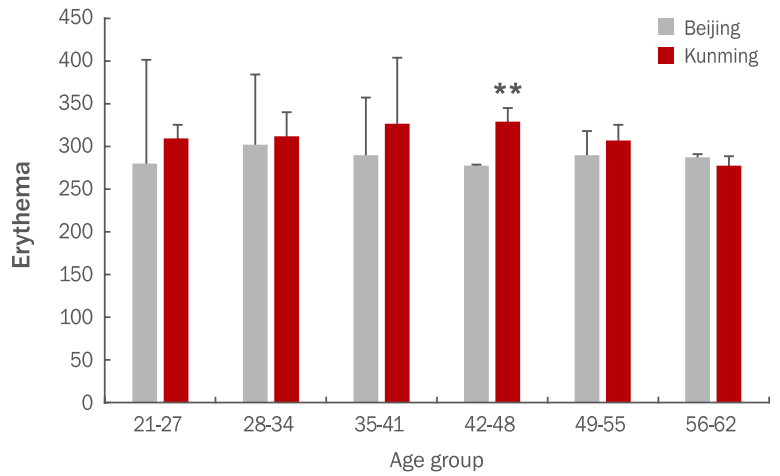

Figure 7. Mean values of erythema arranged by age group and cities.

150 women residing in Beijing and 173 women residing in Kunming were recruited and categorized as age 21-27, age 28-34, age 35-41, age 42-48, age 49-55, age 56-62. Skin erythema were measured with Mexameter MX18. Skin erythema of Kunming was general higher than Beijing and significantly higher in 42-48 year-old age group. The data were expressed as $\mathrm{M} \pm \mathrm{SD}$ and the significant differences were analyzed by independent $t$ test method. $M \pm S D$, mean \pm standard deviation; ${ }^{* *} p<0.01$.

in contact with the skin for only a few seconds. Three individual measurements were taken with the Mexameter to give three hemoglobin and melanin indices and the mean was used for analysis. The Mexameter calibration was evaluated on a weekly basis as per the manufacturer's specifications (Nedelec et al., 2016).

All measurements were performed in triplicate, and the average of these three measurements was calculated and used for group statistics.

\section{Statistical analysis}

Statistical analysis was performed by Statistical Package for the Social Science (SPSS) 22.0 software. All data were expressed as mean $\pm \mathrm{SD}$ and statistical difference of skin biophysical properties among cities were calculated by independent $t$ test (significance level $p<0.05$ ).

\section{Results}

\section{Skin hydration}

As shown in Figure 2, there were no significant differences in the skin hydration between these two cities in all groups. But the trend of the average moisture content in Kunming women was higher than Beijing in every age group.

\section{Skin transepidermal water loss}

As shown in Figure 3, TEWL values in Kunming were general lower than in Beijing for each age groups and significantly decreases at age in the 42-48-yearold age $(p<0.05), 49-55-$ year-old age $(p<0.05)$, and $56-62-$ year-old age group $(p<0.05)$. The lowest TEWL with a measuring value of $9.61 \pm 1.98 \mathrm{~g} / \mathrm{m}^{2} / \mathrm{h}$ was in 56-62-year-old age in Kunming.

\section{Sebum excretion rate}

As shown in Figure 4, sebum secretion rate in Kunming women was gradually reduced with increasing age while the sebum excretion was fluctuated in Beijing women. As can be seen in Figure 3, there was a significant lower of sebum secretion rate in Kunming women than that in Beijing in the 49-55-year-old age $(p<0.01)$. The highest sebum was measured at 35-41-years-old in Beijing (38.46 \pm 13.43$)$, whereas 56-62-years-old in Kunming showed the lowest mean sebum $(8.19 \pm 2.83)$. The reasons for the high SD value were the individual large difference of skin sebum excretion rate.

\section{Skin $\mathrm{pH}$}

As shown in Figure 5, the change of $\mathrm{pH}$ values in all age groups was not obviously, either in Beijing or in Kunming. In addition, there were no significant differences in the skin $\mathrm{pH}$ between Beijing and Kunming women for all groups, but the mean values of $\mathrm{pH}$ in Kunming was generally higher than Beijing in the each age group. The highest $\mathrm{pH}$ was found in group

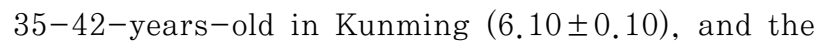
lowest $\mathrm{pH}$ was found in group 28-34-years-old in Beijing $(5.87 \pm 0.56)$.

\section{Melanin}

Figure 6 showed the comparison of skin melanin among the Beijing and Kunming by age group. Skin melanin of Kunming was generally higher than Beijing. Specifically, the increase was very significant between the female subjects aged 28-34-year-old age and 42-48-year-old age $(p<0.001)$. There are moderate significantly increasing 
in skin melanin of women came from Kunming women at age group 35-41-year-old age $(p<0.01)$. The highest melanin index was measured at 42-48-year-old age in Kunming (208.10 \pm 15.56$)$ and the lowest melanin index was measured at 28-34-year-old age in Beijing (145.13 $\pm 103.24)$.

\section{Erythema}

Figure 7 showed the comparison of skin erythema among the Beijing and Kunming by age group. Skin erythema of Kunming was general higher than Beijing and significantly higher in 42-48-year-old age group $(p<0.01)$. The highest erythema index was measured at 42-48-year-old age in Kunming (329.98 16.97) and the lowest erythema index was measured at 56-62-year-old age in Kunming (276.42 \pm 13.43$)$.

\section{Discussion}

The primary objective of this study was to quantitatively measure the difference in skin biophysical parameters between Beijing and Kunming females so that it could help consumers improve skincare strategy and cosmetic enterprises devise cosmetics product more targeted. Generally, the findings of our study showed that Kunming women have lower sebum secretion and TEWL, higher hydration, MI and EI than Beijing women.

\section{Skin hydration}

Hydration refers to the water content of the stratum corneum and is one of the important skin properties for evaluation of stratum corneum barrier function (Hadi et al., 2016). The increase in skin hydration indicates intact skin barrier function. Our research showed that the skin hydration of females living in Kunming city was higher than that living in Beijing. The higher levels of skin hydration in Kunming city might owe to the higher rainfall amount, which was consistent with previous findings that skin surface hydration was found to be strongly affected by both environmental parameters such as temperature and relative humidity (Cravello \& Ferri, 2008). Allan found that relative humidity $(\mathrm{RH})$ effects the rate of desquamation by modulating the activity of the desquamatory enzymes, and specifically stratum corneum chymotryptic enzyme (SCCE) (Watkinson et al., 2001). Exposure to a dry environment leads to depletion of water from the peripheral stratum corneum layers.

\section{Skin transepidermal water loss}

Transepidermal water loss is one of the important indicators for judgment of skin barrier function. Elevated TEWL values are observed in a number of diseases with skin barrier abnormalities (Darlenski \& Fluhr, 2012). TEWL measurement can be affected by several factors including amount of water intake as well as use of moisturisers (Hadi et al., 2016).

Beijing is windy when in the spring, which may be the reason why Beijing women have higher TEWL than Kunming women. The wind will take more away the skin's surface water, resulting in high transepidermal water loss in skin. This differences is more obvious in elderly group, maybe the reason is that with the age increasing, the skin barrier is abate (Roskos \& Guy, 1989). Besides, airborne dust could reduce skin barrier function (Pan et al., 2015). Haze weather in Beijing may be another factor for the increase of transepidermal water loss.

\section{Sebum excretion rate}

Sebaceous lipids contribute to the integrity of the skin barrier supplying the stratum corneum with the hydration (Fluhr et al., 2003; Pilgram et al., 2001) providing photo-protection, particularly against UVB (Marques et al., 2002). We found sebum secretion decreased with the age, and sebum excretion retain Beijing were higher than Kunming. The difference of results may owe to geographic and living habits differences. The sebaceous glands activity is abate with the increase of age (Pochi et al., 1979), so the skin sebum excretion rate gradual declines. It was reported that ethnic differences in the structural properties of facial pores exist and enlarged pore sizes are associated with sebum levels (Sugiyama-Nakagiri et al., 2009). Because of the minority nationalities diversity in Kunming, ethnic intermarriage may contribution to the different of sebum excretion level. The sebum secretion is also related to life stress and emotions (Zouboulis \& Böhm, 2004). The fast pace of life and irregular routine in Beijing exert more pressure to body, which may cause 
the disorder of endocrine and show more sebum secretion (Feng, 2012).

\section{Skin $\mathrm{pH}$}

The skin $\mathrm{pH}$ is usually weak acid under the influence of physiological properties of stratum corneum such as deamination of filaggrin-derived histidine, phospholipid hydrolysis (Zlotogorski, 1987). It is reported that there is a negative correlation between skin hydration and skin $\mathrm{pH}$ (Kobayashi \& Tagami, 2004; Pratchyapruit et al., 2007) which is reversed to our result. The results may be caused differences in the measurement device, race and age (Berardesca \& Maibach, 2003; Rawlings, 2006). Further studies are required to be investigated.

\section{Melanin and erythema}

Melanin and erythema are also factors of skin color and the UV exposed regions have higher erythema and melanin index than protected skin (Kleesz et al., 2012; Kobayashi \& Tagami, 2004; Schnetz et al., 1999). Because of the high altitude, Kunming has the stronger ultraviolet radiation than Beijing while the sun protection consciousness of Kunming women is not as stronger as Beijing women (Cheng, 2008). The major acute effects of UV irradiation on normal human skin comprised sunburn inflammation (erythema), tanning, and local or systemic immunosuppression. At the molecular level, UV irradiation causes DNA damage such as cyclobutane pyrimidine dimers and (6-4) photoproducts. Chronic exposure to UV irradiation leads to photoaging, immunosuppression, and ultimately photocarcinogenesis (Matsumura \& Ananthaswamy, 2004).

\section{Conclusion}

The findings of our study testified that geographical influences skin condition. External circumstances and living habit were both factors which influence the skin physiological parameters. Skin hydration, sebum secretion, melanin, erythema and TEWL were all subject to regions variations. Kunming women show lower sebum secretion, higher hydration, TEWL, MI and EI than Beijing women. These findings provide a registry of data for healthy women living in Beijing and Kunming city. However, further studies are required to elucidate the effects of gender, facial area, and age on environment changes. These findings will have potential applications in dermatology and in the development of new facial skincare products, cosmetics, and topical medicines.

\section{References}

Berardesca E, Maibach H. Ethnic skin: overview of structure and function. Journal of the American Academy of Dermatology, 48: S139-142, 2003.

Cheng SW, Liu F, Cao M, Liu CL, Tong CG, Zhang X, He YL. Knowledge and the use of about sunscreen among Chinese population in Beijing. The Chinese Journal of Dermatovenereology, 22: 566-569, 2008.

Cravello B, Ferri A. Relationships between skin properties and environmental parameters. Skin Research and Technology, 14: 180-186, 2008.

Darlenski R, Fluhr JW. Influence of skin type, race, sex, and anatomic location on epidermal barrier function. Clinics in Dermatology, 30: 269-273, 2012.

Darlenski R, Sassning S, Tsankov N, Fluhr JW. Non-invasive in vivo methods for investigation of the skin barrier physical properties. European Joumal of Pharmaceutics and Biopharmaceutics, 72: 295-303, 2009.

Feng X. Syndrome differentiation in endocrine disease. Guangming Journal of Chinese Medicine, 27: 1869-1870, 2012.

Firooz A, Sadr B, Babakoohi S, Sarraf-Yazdy M, Fanian F, KazerouniTimsar A, Nassiri-Kashani M, Naghizadeh MM, Dowlati Y. Variation of biophysical parameters of the skin with age, gender, and body region. Scientific World Journal, 2012: 386936, 2012.

Fluhr JW, Mao-Qiang M, Brown BE, Wertz PW, Crumrine D, Sundberg JP, Feingold KR, Elias PM. Glycerol regulates stratum corneum hydration in sebaceous gland deficient (asebia) mice. Journal of Investigative Dermatology, 120: 728-737, 2003.

Hadi H, Awadh Al, Hanif NM, Md Sidik NF, Mohd Rani MR, Suhaimi MS. The investigation of the skin biophysical measurements focusing on daily activities, skin care habits, and gender differences. Skin Research and Technology, 22: 247-254, 2016. 
Hillebrand GG, Miyamoto K, Schnell B, Ichihashi M, Shinkura R, Akiba S. Quantitative evaluation of skin condition in an epidemiological survey of females living in northern versus southern Japan. Journal of Dermatological Science, 27: S42-S52, 2001.

Kleesz P, Darlenski R, Fluhr JW. Full-body skin mapping for six biophysical parameters: baseline values at 16 anatomical sites in 125 human subjects. Skin Pharmacology and Physiology, 25: 25-33, 2012.

Kobayashi H, Tagami H. Distinct locational differences observable in biophysical functions of the facial skin: with special emphasis on the poor functional properties of the stratum corneum of the perioral region. International Journal of Cosmetic Science, 26: 91-101, 2004.

Lee MR, Nam GW, Jung YC, Park SY, Han JY, Cho JC, Suh KD, Hwang JK. Comparison of the skin biophysical parameters of Southeast Asia females: forehead-cheek and ethnic groups. Journal of the European Academy of Dermatology and Venereology, 27: 1521-1526, 2013.

Man MQ, Xin SJ, Song SP, Cho SY, Zhang XJ, Tu CX, Feingold KR, Elias PM. Variation of skin surface $\mathrm{pH}$, sebum content and stratum corneum hydration with age and gender in a large Chinese population. Skin Pharmacology and Physiology, 22: 190-199, 2009.

Marques M, Pei Y, Southall MD, Johnston JM, Arai H, Aoki J, Inoue T, Seltmann $\mathrm{H}$, Zouboulis CC, Travers JB. Identification of plateletactivating factor acetylhydrolase II in human skin. Journal of Investigative Dermatology, 119: 913-919, 2002.

Matsumura Y, Ananthaswamy HN. Toxic effects of ultraviolet radiation on the skin. Toxicology and Applied Pharmacology, 195: 298-308, 2004.

Nedelec B, Forget NJ, Hurtubise T, Cimino S, de Muszka F, Legault A, Liu WL, de Oliveira A, Calva V, Correa JA. Skin characteristics: normative data for elasticity, erythema, melanin, and thickness at 16 different anatomical locations. Skin Research and Technology, 22: 263-275, 2016.

Pan TL, Wang PW, Aljuffali IA, Huang CT, Lee CW, Fang JY. The impact of urban particulate pollution on skin barrier function and the subsequent drug absorption. Journal of Dermatological Science, 78: 51-60, 2015.

Pilgram GS, van der Meulen J, Gooris GS, Koerten HK, Bouwstra JA. The influence of two azones and sebaceous lipids on the lateral organization of lipids isolated from human stratum corneum. Biochimica et Biophysica Acta, 1511: 244-254, 2001.
Pochi PE, Strauss JS, Downing DT. Age-related changes in sebaceous gland activity. Journal of Investigative Dermatology, 73: 108-111, 1979.

Pratchyapruit W, Kikuchi K, Gritiyarangasan P, Aiba S, Tagami H. Functional analyses of the eyelid skin constituting the most soft and smooth area on the face: contribution of its remarkably large superficial corneocytes to effective water-holding capacity of the stratum corneum. Skin Research and Technology, 13: 169-175, 2007.

Rawlings AV. Ethnic skin types: are there differences in skin structure and function? International Journal of Cosmetic Science, 28: 79-93, 2006.

Roskos KV, Guy RH. Assessment of skin barrier function using transepidermal water loss: effect of age. Pharmaceutical Research, 6: 949-953, 1989.

Schnetz E, Kuss O, Schmitt J, Diepgen TL, Kuhn M, Fartasch M. Intra-and inter-individual variations in transepidermal water loss on the face: facial locations for bioengineering studies. Contact Dermatitis, 40: 243-247, 1999.

Sugiyama-Nakagiri Y, Sugata K, Hachiya A, Osanai O, Ohuchi A, Kitahara T. Ethnic differences in the structural properties of facial skin. Journal of Dermatological Science, 53: 135-139, 2009.

Tian HD. Huang di nei jing suwen. People's Medical Publishing House, Beijing, p2, 2005.

Wan MJ, Su XY, Zheng Y, Gong Z, Yi JL, Zhao Y, Guan XM, Lai W. Seasonal variability in the biophysical properties of forehead skin in women in Guangzhou city, China. International Journal of Dermatology, 54: 1319-1324, 2015.

Watkinson A, Harding C, Moore A, Coan P. Water modulation of stratum corneum chymotryptic enzyme activity and desquamation. Archives of Dermatological Research, 293: 470-476, 2001.

Yamashita Y, Okano Y, Ngo T, Buche P, Sirvent A, Girard F, Masaki $H$. Differences in susceptibility to oxidative stress in the skin of Japanese and French subjects and physiological characteristics of their skin. Skin Pharmacology and Physiology, 25: 78-85, 2012.

Zlotogorski A. Distribution of skin surface $\mathrm{pH}$ on the forehead and cheek of adults. Archives of Dermatological Research, 279: 398-401, 1987.

Zouboulis CC, Böhm M. Neuroendocrine regulation of sebocytes: a pathogenetic link between stress and acne. Experimental Dermatology, 13: 31-35, 2004. 


\section{中文摘要}

\section{北京与昆明女性居民皮肤生理指标的比较}

何一凡，岳立芝，董银卯，李丽，孟宏*

北京工商大学中国化妆品协同创新中心，北京，中国

目的：探讨北京和昆明地区女性面部皮肤生理指标的差异，为不同地区的消费者提供实际应用指导。同时，本 研究将有助于化妆品企业根据不同地区的特点, 设计出更具针对性的化妆品产品。方法: 本研究纳入北京和昆 明323名年龄在21岁至69岁之间的健康女性, 进行6个非侵入性皮肤生理指标的测量, 包括水分含量, 经皮水 分流失（trans-epidermal water loss, TEWL），皮脂含量，pH值，黑色素含量（melanin index，MI）， 红色素含量（erythema index，EI）。结果：北京和昆明女性居民皮肤生理指标具有显著差异。相比北京女性 居民，昆明女性皮肤皮脂和经皮水分流失量较低，较高的水化，MI和EI比北京女人。结论: 区域是影响皮肤生 理参数的重要因素。外界环境和生活习惯的差异都是影响皮肤状况的因素。研究不同地区女性居民皮肤生理指 标对于制定合适的护肤策略和研发个性化化妆品至关重要。

关键词: 皮肤生理指标，女性，北京，昆明，经皮水分流失 


\section{국문초록}

\section{북경과 쿤밍 지역 여성의 피부 생물 물리학적 매개변수 비교}

하일범, 악립지, 동은묘, 리려, 맹홍*

북경공상대학 중국화장품공동혁신센터, 북경, 중국

목적: 본 연구는 베이징과 쿤밍 지역 여성들의 안면피부의 생물 물리학적 변수들의 차이를 조사하여 다른 지역의 소비자들에게 실 용적인 적용지침을 제공하는 것을 목적으로 한다. 또한 본 연구는 화장품 회사가 지역 특성에 따른 보다 더 표적화 된 화장품을 개 발하는데 도움을 줄 것이다. 방법: 본 연구는 북경과 쿤밍 지역의 21-29세, 323 명의 건강한 여성에 대해 비 침습적 방법으로 수분 함량, 경피수분손실량(trans-epidermal water loss, TEWL), 피지함량, $\mathrm{pH}$, 멜라닌 지수(melanin index, MI) 및 홍반지수(erythema index, EI) 등 6 가지 생물학적 특성을 측정하였다. 결과: 북경과 쿤밍 지역 여성들의 안면피부의 생물 물리학적 매개변수의 지역별 차이는 매우 컸다. 일반적으로 쿤밍 여성은 북경 여성보다 피지 분비 및 TEWL이 낮고, 수분 공급량이 많았으며, 멜라닌 지수 및 홍 반 지수가 높았다. 결론: 지역은 피부의 생물 물리학적 변수에 영향을 주는 중요한 요소이며 외부 환경과 생활습관 차이도 피부상 태에 영향을 주는 요소이다. 다른 지역들 간의 피부 생물 물리학적 매개변수에 대한 연구는 적절한 스킨케어 전략을 수립하고, 개인 맞춤 화장품을 만드는데 필수적이라 사료된다.

핵심어: 피부 생물물리학적 매개변수, 여성, 북경, 쿤밍, 경피수분손실 